\title{
Soil Properties and Their Effect on Some Biological Activities in Abu Suberia Valley- Aswan, Egypt
}

\author{
Alshaymaa Ibrahim Ahmed Ali ${ }^{1}$, Samir Mahgoub ${ }^{2}$, N.M.A. Bahnasawy ${ }^{3}$ and \\ Salah Tahoun ${ }^{4}$ \\ ${ }^{1}$ Microb. Dept., Fac. Agric., Aswan Univ., ${ }^{2}$ Microb. Dept., Fa. Agric., Zag. Univ., ${ }^{3}$ Soil \\ Chem. and Phys. Dep., DRC and ${ }^{4}$ Soil Sci. Dep., Fac. Agric., Zag. Univ. Egypt.
}

$\mathbf{T}$

The present study includes combined soil and biological aspects of Abu Suberia valley. Twelve representative soil surface samples, down to $20 \mathrm{Cm}$.were collected and subjected to detailed soil analyses.

The obtained results reveal that, soil texture ranges from sand to heavy clay, $\mathrm{CaCO}_{3}$ content is widely variable (0.08-7.21\%) and organic matter (OM) content is low ( $0.02-2.47 \%)$. pH is neutral to mildly alkaline. The soil samples are non-saline to saline, mostly non-saline. The cationic composition is mostly dominated by $\mathrm{Na}^{+}$or $\mathrm{Ca}^{++}$while the anionic composition is mostly dominated by $\mathrm{Cl}^{-}$. Cation exchange capacity ranges widely from $(2.43-38.08 \mathrm{me} / 100 \mathrm{~g}$ soil) with the higher capacity due to clay mineral type and content. Exchangeable cations are dominated with $\mathrm{Ca}^{++}$. Available P ranges from $(0.82-4.77 \mathrm{me} / \mathrm{Kg}$ soil). The mineralogy of clay fraction is dominated by kaolinite as identified by XRD.

Data of biological investigation showed that the total counts of bacteria, fungi, yeast, actinomycetes, thermophilic bacteria and cellulolytic bacteria range from $22.4 \times 10^{6}$ to $284 \times 10^{6}$, $10 \times 10^{3}$ to $27 \times 10^{3}, 6 \times 10^{2}$ to $20 \times 10^{2}, 9 \times 10^{3}$ to $19 \times 10^{3}, 31 \times 10^{3}$ to $48 \times 10^{3}, 0.90 \times 10^{4}$ to $1.82 \times 10^{4}$ $\mathrm{CFUg}^{-1}$ dry soil respectively. The nitrifying and denitrifying bacteria range from $38.0 \times 10^{4}$ to $121.0 \times 10^{4}$ and $30.0 \times 10^{2}$ to $65.0 \times 102 \mathrm{MPN} \mathrm{g}^{-1}$ dry soil, respectively. The biological activities of the concerned enzymes were also recorded and interpreted.

Statistical evaluation reveals that soil OM, $\mathrm{pH}, \mathrm{EC}_{\mathrm{e}} \mathrm{Ca}^{++}, \mathrm{Na}^{+}, \mathrm{Cl}^{-}, \mathrm{SO}_{4}^{--}$and exchangeable $\mathrm{Na}$ are correlated well with total counts of most bacteria, fungi and actinomycetes. Also, OM is correlated with dehydrogenase, alkaline phosphatase and urease.

Keywords: Abu Suberia valley, Soil properties, Clay mineralogy, Fungi, Yeast, Actinomycetes bacteria, Enzymes, Statistical correlation.

\section{Introduction}

The study aimed to show the effect of soil properties on biological activities in Abu Suberia valley- Aswan, Egypt.

Abu Suberia valley is one of several valleys in the southern extremities of the Eastern Desert embedded in the Nubian sandstone formation of the region. It extends along an east - west axis for about $60 \mathrm{~km}$, and its mouth on the Nile is located about $30 \mathrm{~km}$ north of Aswan city. The prevailing climatic conditions are typical arid to hyperarid.

A number of studies documented the role of microorganisms in soil fertility and soil quality (Caldwell, 2005, Bhattacharyya et al., 2008 and Avanthi et al., 2017). Moreover, the correlation between soil microorganisms and some soil properties was also considered since these properties, or some of which, exert negative of positive influence on their behaviour. Among

Corresponding author: E-mail: nabilmohamed597@gmail.com

DOI: $10.21608 /$ ejss.2018.1972.1138

(C)2018 National Information and Documentation Centre (NIDOC) 
the recent studies the formation of biofilm on clay minerals and some soil minerals have been recorded due to adhesion of bacteria on soil surface .Also, the formation, translocation and biodegradation of clay minerals enhanced by specific bacteria were also investigated.

In Abu Suberia valley, the soil properties and microorganisms together with microbial and biological activities were not studied. Therefor it is of interest to throw light on soil properties as correlated with microbiological activities. Accordingly, the represent work is conducted to illustrate the nature of soils in this valley, microbiological, enzymatic activity status and behaviour.

Microorganisms being in intimate contact with the soil environment are considered to be the best indicators of soil fertility and pollution. In general they are very sensitive to low concentration of contaminants and rapidly respond to soil perturbation. An alteration of their activity and diversity may reflect the reduced soil quality (Schloter et al., 2003). Soil enzyme activities are the driving force behind all biochemical transformations occurring in soil. Their evaluation may provide useful information on soil microbial activity and be helpful in establishing the effects of soil specific environmental conditions Andreoni et al. (2004). Soil microbes are important reflection for soil quality and enzyme activity involved in the biogeochemical cycling of carbon, nitrogen, phosphorus, sulphur and other nutrients Caldwell,(2005). Soil enzyme activities have been generally accepted as one of the diagnostic indices of soil fertility quality and can quantify change as a result of human disturbance. Application of enzyme activity as a diagnostic index promotes high sensitivity to external effects, simplicity of definition and low errors Bhattacharyya et al. (2008).

Statistical evaluation of such correlation was also worked out to define the role of soil properties in the status and activities taken place due to biological activities.

\section{Materials And Methods}

\section{Analysis of soil samples}

Abu Suberia valley is extended over the study area in east - west direction along $60 \mathrm{Km}$. The sampling sites total 12 according to the variations encountered in the soil matrix Fig. (1). The surface soil samples were collected down to $20 \mathrm{Cm}$., to represent the soil variations in Abu Suberia valley on which microorganisms and biological activities are studied and evaluated.

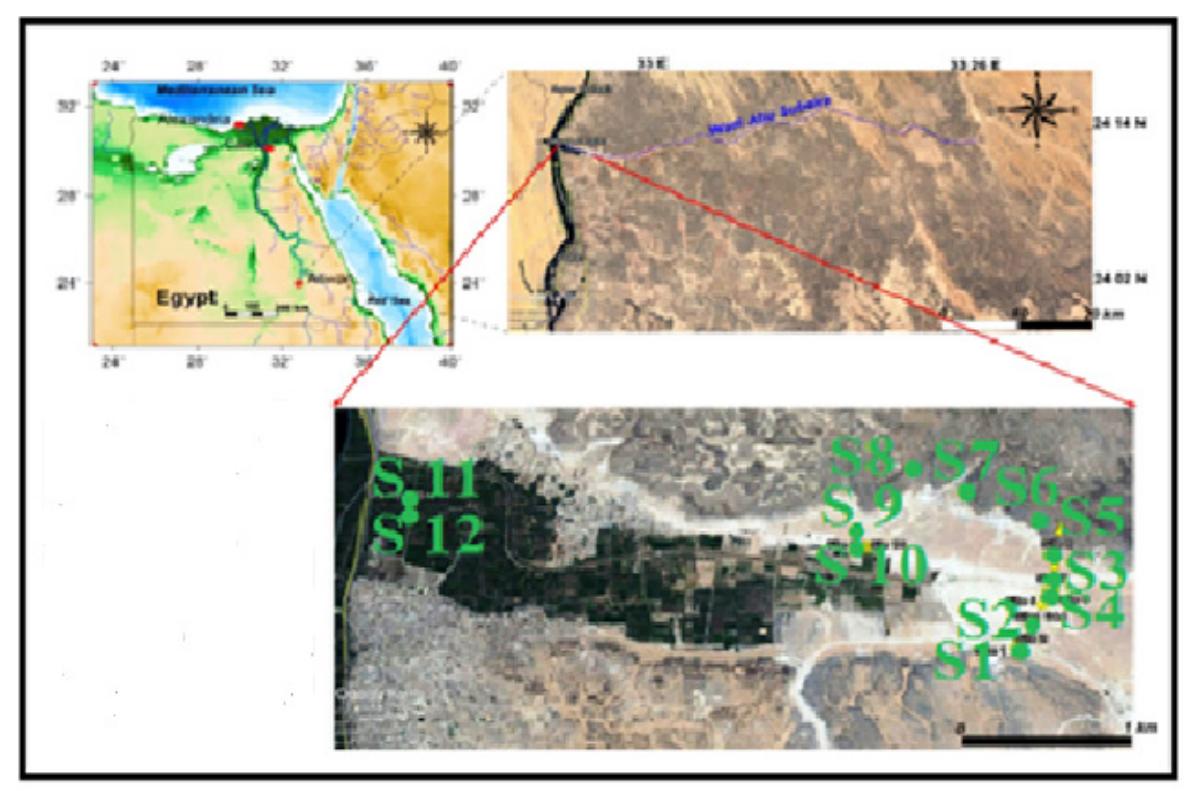

Note. $\mathrm{S}=$ Site.

Fig. 1. Soil sites of Abu Subeira valley-Aswan, Egypt heated to $550{ }^{\circ} \mathrm{C}$ for $4 \mathrm{hrs}$. Identification of clay and non-clay minerals was carried out following the criteria established by Li and Schoonmaker (2003) and Ehrmann et al. (2005)

Egypt. J. Soil. Sci. 58, No. 2 (2018) 
The representative soil samples were air dried, crushed by hand, sieved through a $2 \mathrm{~mm}$ sieve then subjected to the following analyses:

- Calcium carbonate content was determined using Collin〉s calcimeter, (USDA, 2010);

- Organic matter content was determined as recommended by De Vos et al. (2007).

- Particle size distribution by the pipette method, (Syvitski and James, 2007);

- Soil reaction $(\mathrm{pH})$ was determined in the soil saturation extract using a $\mathrm{pH}$ meter, 3320 Jenway (Gavlak et al., 2005);

- Total soil salinity (ECe) was measured in the soil saturation extract using a conductance meter, YSI model (35) and soluble cations and anions were determined (Soil Survey Staff., 2009);

- Cation exchange capacity (CEC) and exchangeable cations were determined using the methods described by Dawid and Dorota (2014);

- Available phosphors (P) was determined by Silva et al. (2007). Separation of the clay fraction (less than $2 \mu$ ) collected from 7 sites was carried out after the essential pretreatments,i.e., the removal of soluble salts, carbonates, organic matter and iron oxides. The separated clays were X-rayed in a Philips PW 3710 installation supplied with a horizontal goniometry and a vertical object plane, using Ni-filtered $\mathrm{Cu} \alpha$ radiation (40 Kv operating voltage and current of $35 \mathrm{~m} \AA$ ). The X-ray diffraction analysis was carried out on the Mg-saturated air-dried; Mg-saturated glycerol solvated; K-saturated air- dried; and K-saturated clay samples

\section{Microbiological analysis of soil samples}

Counts of microorganisms were estimated by the dilution plate technique methods (Becky et al., 2001). The following microbial analyses (i.e., total bacterial count (TBC), total fungi count (TFC), total yeast count (TYC), total actinomycetes count (TAC), total thermophilic bacterial count (TTBC), total cellulolytic bacterial count (TCBC), total nitrifying bacterial count (TNBC) and total denitrifying bacterial count (TDBC) were carried out in all soil samples according to Ben-David \& Davidson (2014) and Pious et al. (2015).

\section{Nitrifiers enrichment medium}

Nitrifiers were enriched on according to Hirotsugu et al. (2015), two different media by Maite et al. (2005). Nitrifying bacteria were enumerated by the MPN technique using both modified media of Maite et al. (2005). As a control, nitrite and nitrate were assayed using the standard chemical method (Griess-Ilosvay reagent) after 8 weeks by Zhao et al. (2015). A Most probable number (MPN) (WHO and Switzerland, 2017) was used to determine numbers of nitrifying bacteria. Nitrifies were enriched on medium containing (g/l) by Bridson (2006), two different media by Matsumoto et al. (2010).

\section{Soil enzyme activities}

Soil dehydrogenase, alkaline phosphatase and urease activities were analyzed following the methods described by Peters et al. (2003).

\section{$\underline{\text { Results and Discussion }}$}

\section{Soil properties}

Data in Table 1 showed that the selected samples have variable soil texture classes ranging from sand to heavy clay according to the ISSS, (International Soil Science Society) by Julien (2016). Out of which, the dominant texture is light to heavy clay (5 samples) and sandy loam (3 samples). Other soil samples have sand to loamy sand and one sandy clay loam texture. $\mathrm{CaCO}_{3}$ content is widely variable between 0.08 and 7.21 $\%$, indicating non-calcareous soil conditions. Organic matter content is extremely low, being in the range 0.02 to $2.47 \%$, the lowest and highest contents are recorded in sites 8 and 3 , respectively.

Table 2 reveals that the soil reaction is neutral to mildly alkaline as indicated by $\mathrm{pH}$ values $(6.97-8.00)$. The soil samples are non-saline to saline as shown by EC values which range from 0.65- $9.50 \mathrm{dS} / \mathrm{m}$. To suffices, most soil samples are non-saline except for sample 2 (slightly saline), samples 7 and 8 (saline). The cationic composition of the soil saturation extract follows three orders where $\mathrm{Na}^{+}$is the dominant cation followed by $\mathrm{Ca}^{++}>\mathrm{Mg}^{++}>$and $\mathrm{K}^{+}$in five samples while $\mathrm{Na}^{+}$ is followed by $\mathrm{Mg}^{++}$only in one sample (site 3). The second order is $\mathrm{Mg}^{++}$followed by $\mathrm{Ca}^{++}$and /or $\mathrm{Na}^{+}$while $\mathrm{K}^{+}$is the least soluble cation. The third order is $\mathrm{Ca}^{++}$followed by $\mathrm{Na}^{+}$and / or $\mathrm{Mg}^{++}$while $\mathrm{K}^{+}$is the least. In all cases, $\mathrm{Na}^{+}$or $\mathrm{Mg}^{++}$or $\mathrm{Ca}^{++}$ predominates but still $\mathrm{Na}^{+}$predominates in six samples while each of $\mathrm{Ca}^{++}$and $\mathrm{Mg}^{++}$predominate in three samples only. Moreover, $\mathrm{K}^{+}$is the least abundant soluble cation. The anionic composition of the soil saturation extract follows three orders of which $\mathrm{Cl}^{-}>\mathrm{SO}_{4}^{--}>\mathrm{HCO}_{3}^{-}>\mathrm{CO}_{3}^{--}$is the most abundant and $\mathrm{Cl}^{-}>\mathrm{HCO}_{3}^{-}>\mathrm{SO}_{4}^{--}>\mathrm{CO}_{3}^{--}$is the second abundant and the third order presents the abundance of $\mathrm{HCO}_{3}^{--}$over $\mathrm{Cl}^{-}>\mathrm{SO}_{4}^{--}$and $\mathrm{CO}_{3}^{--}$.

With regard to the exchange characteristics of soil samples, data presented in Table 3 showed that cation exchange capacity (CEC) ranges widely between as low as $2.43 \mathrm{me} / 100 \mathrm{~g}$ soil (site 5) to $38.08 \mathrm{me} / 100 \mathrm{~g}$ soil (site 1 ). As expected, the lowest

Egypt. J. Soil. Sci. 58, No. 2 (2018) 
TABLE 1. Total $\mathrm{CaCO}_{3}$ organic matter contents and particle size distributions of the soils of Abu Suberia valley

\begin{tabular}{|c|c|c|c|c|c|c|c|}
\hline \multirow[b]{2}{*}{ Site No. } & \multirow{2}{*}{$\begin{array}{c}\text { Total } \\
\mathrm{CaCO}_{3} \\
\% \\
\end{array}$} & \multirow{2}{*}{$\begin{array}{c}\text { Organic } \\
\text { matter } \\
\% \\
\end{array}$} & \multicolumn{5}{|c|}{ Particle size distribution \% } \\
\hline & & & $\begin{array}{c}\text { Coarse } \\
\text { sand }\end{array}$ & Fine sand & Silt & Clay & Texture Class \\
\hline 1 & 0.08 & 0.07 & 2.20 & 3.89 & 22.93 & 70.98 & Heavy clay \\
\hline 2 & 6.88 & 0.04 & 32.96 & 18.22 & 10.19 & 38.63 & Light clay \\
\hline 3 & 5.84 & 2.47 & 3.17 & 2.17 & 38.88 & 55.78 & Heavy clay \\
\hline 4 & 1.92 & 0.06 & 82.75 & 4.99 & 1.21 & 11.05 & Loamy sand \\
\hline 5 & 0.63 & 0.09 & 95.53 & 4.35 & 0.03 & 0.09 & Sand \\
\hline 6 & 2.96 & 0.19 & 63.28 & 14.41 & 8.58 & 13.73 & Sandy Loam \\
\hline 7 & 0.50 & 0.29 & 74.42 & 9.27 & 6.04 & 10.27 & Sandy Loam \\
\hline 8 & 7.21 & 0.02 & 67.20 & 13.85 & 3.02 & 15.93 & Sandy clay Loam \\
\hline 9 & 0.63 & 0.72 & 93.82 & 2.85 & 1.18 & 2.15 & Sand \\
\hline 10 & 0.25 & 2.02 & 68.22 & 0.45 & 21.63 & 9.70 & Sandy Loam \\
\hline 11 & 2.38 & 2.30 & 18.69 & 17.66 & 10.65 & 53.00 & Heavy clay \\
\hline 12 & 2.38 & 1.32 & 24.82 & 6.43 & 12.3 & 56.45 & Heavy clay \\
\hline
\end{tabular}

TABLE 2. Soil reaction, salinity and soluble ions of saturation extract of soil samples of Abu Suberia valley

\begin{tabular}{|c|c|c|c|c|c|c|c|c|c|c|}
\hline \multirow{3}{*}{ Site No. } & \multirow{3}{*}{ pH } & \multirow{3}{*}{$\begin{array}{c}E C \\
(d S / m)\end{array}$} & \multicolumn{8}{|c|}{ Soluble ions $\mathrm{mmol} / \mathrm{l}$} \\
\hline & & & \multicolumn{4}{|c|}{ Cations } & \multicolumn{4}{|c|}{ Anions } \\
\hline & & & $\mathrm{Ca}^{++}$ & $\mathbf{M g}^{++}$ & $\mathrm{Na}^{+}$ & $\mathbf{K}^{+}$ & $\mathrm{CO3}^{--}$ & $\mathrm{HCO3}^{-}$ & $\mathrm{Cl}^{-}$ & SO4- $^{-}$ \\
\hline 1 & 7.21 & 1.50 & 4.0 & 5.0 & 5.54 & 0.5 & 0.0 & 2.0 & 6.5 & 6.5 \\
\hline 2 & 7.33 & 5.41 & 11.0 & 7.8 & 34.6 & 0.8 & 0.0 & 1.0 & 41.5 & 11.6 \\
\hline 3 & 7.67 & 1.51 & 7.0 & 4.0 & 3.6 & 0.5 & 0.0 & 3.5 & 8.0 & 3.6 \\
\hline 4 & 7.94 & 0.73 & 2.0 & 1.0 & 3.8 & 0.5 & 0.0 & 2.5 & 3.0 & 1.8 \\
\hline 5 & 7.76 & 0.94 & 3.0 & 2.0 & 3.8 & 0.6 & 0.0 & 3.0 & 5.0 & 1.4 \\
\hline 6 & 7.75 & 1.30 & 4.0 & 4.3 & 4.2 & 0.5 & 0.0 & 3.0 & 6.5 & 3.5 \\
\hline 7 & 7.05 & 6.97 & 15.7 & 8.9 & 44.2 & 0.9 & 0.0 & 1.5 & 55.0 & 12.6 \\
\hline 8 & 6.97 & 9.50 & 21.7 & 12.0 & 60.3 & 1.0 & 0.0 & 6.6 & 73.2 & 15.2 \\
\hline 9 & 7.95 & 1.34 & 4.5 & 4.6 & 3.8 & 0.6 & 0.0 & 4.5 & 6.0 & 2.9 \\
\hline 10 & 7.97 & 0.90 & 2.8 & 2.0 & 3.8 & 0.4 & 1.0 & 3.0 & 4.9 & 0.1 \\
\hline 11 & 7.81 & 1.09 & 3.0 & 10.0 & 3.7 & 0.5 & 0.5 & 4.3 & 4.5 & 1.6 \\
\hline 12 & 8.00 & 0.65 & 1.9 & 0.9 & 3.5 & 0.3 & 0.0 & 3.5 & 2.0 & 1.0 \\
\hline
\end{tabular}

CEC is that of the sandy textured samples (sites 5 and 9) whereas the highest CEC is that of the heavy clay textured samples (sites 1, 3, 11 and 12). The light clay, sandy clay loam, loamy sand and sandy loam samples (2, 4,6,7,8 and 10 have CEC values in between those ranges. Foreshore, the higher and highest CEC values are rendered to clay content, clay mineral type, amorphous inorganic materials and organic matter content. Exchangeable cations are, in all cases, dominated with exchangeable $\mathrm{Ca}^{++}$ followed, in most cases, by exchangeable $\mathrm{Mg}^{++}$and rarely with exchangeable $\mathrm{Na}^{+}$. It is also evident that the least exchangeable cations are either $\mathrm{Na}^{+}$or $\mathrm{K}^{+}$.

Available phosphorus ranges within a relatively narrow limit, 0.82 and $4.77 \mathrm{me} / \mathrm{Kg}$ soil. The least content characterises sample No. 5, while the highest is that of sample No 1 .
It is also clear that higher available phosphorus $(\geq 2.57 \mathrm{me} / \mathrm{Kg}$ soil) characterises the samples No. $1,2,3,6$ and 10, moderate levels of available phosphorus characterizes the samples No. 4, 7, 8, 11 and 12, while samples No. 5 and 9 have the least available phosphorus.

\section{Mineralogy of the clay fraction}

To provide more information about the studied soils, the mineralogical composition of the clay fraction which is the most reactive portion of soils was identified. X- ray diffraction patterns of the clay fractions separated from the seven loamy sand and heavy clay samples are presented in Fig. 2 and identified on the basis of the guidelines provided by Dixon \& Schulze (2002) and Harris \& White (2007) (Table 4).

The obtained results indicate that kaolinite constitutes dominant amounts in all separated clay 
samples except for the clay fraction of sample No. 4 which contains less kaolinite. Illite is detected in few amounts in three samples, slightly higher in samples No. 3 and 12 while being absent in samples 1 and 8 . Halloysite is found in moderate amounts and montmorillonite in traceable amounts only in samples No. 2 and 1, respectively.

Based on the mineralogical composition of clay samples, one can predict the active surface area of the investigated soil samples which does not exceed $50 \mathrm{~m}^{2} / \mathrm{g}$ on which microbial activities take place (Ostafiychuk et al., 2014).

Referring to the location of Abu Suberia Valley, it is apparent that this valley is roughly a triangular- shaped area starting from east to west and covered with soil matrix that varies considerably from one site to another.

The foregoing results sum up the most important soil properties of such valley. The variations in soil properties indicate that soil parent materials are complex and most of soil properties are dependent on the sedimentary regime that prevailed during the soil formation in such valley and landscape which, in turn are reflected on soil properties already presented.

Since the soil samples were used for a growth of bacteria and fungi, and accordingly biological activities the soil properties of these media will be correlated with bacteria, actinomycetes and fungi counts and consequently biological activity of the microorganisms.

\section{Microbial load in soil samples}

Table 5 indicates a considerable variability in microbiological counts of the investigated soil samples, being site dependent to a great extent. The total bacterial count (TBC) ranges from $22.0 \times 10^{6}-284.0 \times 10^{6} \mathrm{CFU} \mathrm{g}^{-1}$ dry soil. The lowest count is detected in soil site 9 , whereas the highest is that of site 3 .

Total fungal counts (TFC) vary from one site to another, being at their lowest count in site 8 while rise up to $27.0 \times 10^{3} \mathrm{CFU} \mathrm{g}^{-1}$ dry soil in site 11 .

Total yeasts count (TYC) ranges from $6 \times 10^{2}$ $20 \times 10^{2} \mathrm{CFU} \mathrm{g}^{-1}$ dry soil, the highest Nos. of counts is recorded in sites 11 and 12 while the lowest is found in soil of site 8 . Distinction of total yeasts count can be made in two major soil groups where total yeasts count has common values in soils of sites $1,3,4,5,6,7,9,10,11$ and 12 on the one hand and sites 2 and 8 .

Regarding total actinomycetes (TAC), the number of counts ranges from $9.0 \times 10^{3}-19.0 \times 10^{3}$ CFU g ${ }^{-1}$ dry soil, the lowest count was that in sites 2 and 8 while the highest was that of site 3 . With respect to total thermophilic bacteria (TTBC), the counts ranged from $31.0 \times 10^{3}$ to $48.0 \times 10^{3} \mathrm{CFU}$ $\mathrm{g}^{-1}$ dry soil, the lowest count was found in site 2 and the highest in site 3 .

With respect to total cellulolytic bacterial count (TCBC) counts, they can be categorized into two patterns. The first included TCBC in sites $1,2,3,4,5$ and 8 to the second included sites $6,7,9$, 10, 11 and 12. Again, the variations encountered are surely dependent on certain soil properties that will be figured out latter.

As to the total nitrifying bacterial count (TNBC), it is also clear that the presented counts could be categorise into three groups; the first group included sits 1, 2, 4 and 8, second groups included sites $3,9,10,11$ and 12 , at least the third groups included 5, 6 and 7, (TDBC) total denitrifying bacterial count ranges from $\left(30.0 \times 10^{2}\right.$ to $65.0 \times 10^{2} \mathrm{MPN} \mathrm{g}^{-1}$ dry soil).

TABLE 3. Exchange characteristics and available phosphorus in of the studied soil samples of Abu Suberia valley

\begin{tabular}{|c|c|c|c|c|c|c|}
\hline \multirow{2}{*}{ Site No. } & \multirow{2}{*}{$\begin{array}{c}\text { CEC } \\
\text { me/100g soil }\end{array}$} & \multicolumn{4}{|c|}{ Exchangeable cations (me/100g soil) } & \multirow{2}{*}{$\begin{array}{r}\text { Available } P \\
\text { (me/Kg soil) }\end{array}$} \\
\hline & & $\mathbf{C a}^{++}$ & $\mathbf{M g}^{++}$ & $\mathbf{N a}^{+}$ & $\mathbf{K}^{+}$ & \\
\hline 1 & 38.08 & 25.60 & 9.50 & 1.99 & 0.99 & 4.77 \\
\hline 2 & 19.35 & 9.40 & 2.65 & 6.22 & 1.08 & 3.15 \\
\hline 3 & 21.63 & 17.72 & 2.42 & 0.46 & 1.03 & 2.57 \\
\hline 4 & 12.70 & 11.54 & 0.88 & 0.14 & 0.14 & 1.17 \\
\hline 5 & 2.43 & 1.20 & 1.20 & 0.01 & 0.02 & 0.82 \\
\hline 6 & 9.00 & 7.72 & 0.74 & 0.23 & 0.31 & 3.69 \\
\hline 7 & 7.28 & 3.75 & 2.48 & 0.81 & 0.24 & 1.18 \\
\hline 8 & 8.80 & 4.20 & 1.98 & 2.30 & 0.24 & 1.88 \\
\hline 9 & 2.99 & 2.22 & 0.62 & 0.08 & 0.07 & 0.85 \\
\hline 10 & 6.70 & 5.19 & 1.30 & 0.15 & 0.06 & 3.31 \\
\hline 11 & 16.43 & 8.95 & 6.13 & 0.59 & 0.76 & 1.40 \\
\hline 12 & 14.24 & 7.02 & 5.60 & 0.60 & 1.02 & 1.85 \\
\hline
\end{tabular}




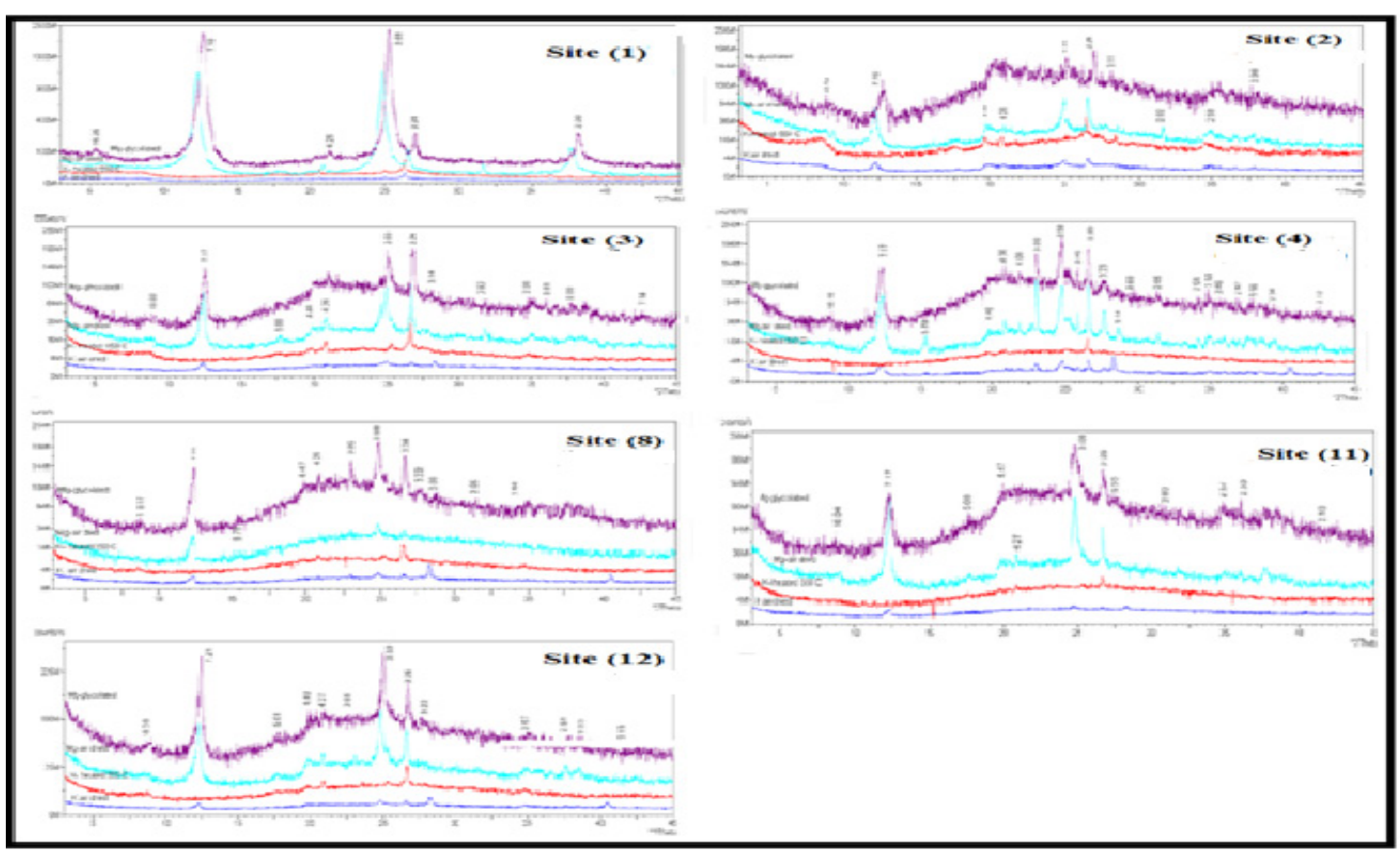

Fig. 2. X-Ray diffractograms of the clay fraction separated from the studied soil samples in valley Abu Suberia

TABLE 4. Mineralogy of the clay fraction of some soil samples of Abu Suberia Valley

\begin{tabular}{ccccc}
\hline \multirow{2}{*}{ Site No. } & \multicolumn{3}{c}{$\%$} \\
\cline { 2 - 5 } & Kaolinite & Illite & Halloysite & Montmorillonite \\
\hline 1 & $* * * * *$ & - & - & $*$ \\
2 & $* * * * *$ & $* *$ & $* * *$ & - \\
3 & $* * * * *$ & $* * * *$ & - & - \\
4 & $* * * *$ & $* *$ & - & - \\
8 & $* * * * *$ & - & - & - \\
11 & $* * * * *$ & $* *$ & - & - \\
12 & $* * * * *$ & $* * *$ & - & - \\
\hline None $-;$ Traces $*<5$, Few & $* * 5-15 \% ;$ Moderate $* * * 15-25 \% ;$ Common $* * * * 25-40 \%$ and Dominant $* * * * * 40 \%$.
\end{tabular}

TABLE 5. Microbiological analysis of the different soil sites in Abu Suberia valley

\begin{tabular}{|c|c|c|c|c|c|c|c|c|}
\hline \multirow{3}{*}{$\begin{array}{l}\text { Site } \\
\text { No. }\end{array}$} & \multicolumn{6}{|c|}{ CFU g g-1ry soil } & \multicolumn{2}{|c|}{ MPN $g^{-1}$ dry soil } \\
\hline & TBC & TFC & TYC & TAC & TTBC & TCBC & TNBC & TDBC \\
\hline & $\mathbf{x 1 0 ^ { 6 }}$ & $\times 10^{3}$ & $\mathbf{x} 10^{2}$ & $\mathbf{x} 10^{3}$ & $\mathbf{x} 10^{3}$ & $\times 10^{4}$ & $\times 10^{4}$ & $\mathbf{x} 10^{2}$ \\
\hline 1 & 95.0 & 18.0 & 13.0 & 11.0 & 36.0 & 0.95 & 56.0 & 34.0 \\
\hline 2 & 72.0 & 12.0 & 8.0 & 9.0 & 31.0 & 0.92 & 41.0 & 31.0 \\
\hline 3 & 284.0 & 23.0 & 18.0 & 19.0 & 48.0 & 0.98 & 121.0 & 65.0 \\
\hline 4 & 85.0 & 13.0 & 10.0 & 10.0 & 33.0 & 0.94 & 53.0 & 32.0 \\
\hline 5 & 107.0 & 15.0 & 12.0 & 12.0 & 36.0 & 0.95 & 72.0 & 39.0 \\
\hline 6 & 162.0 & 18.0 & 14.0 & 13.0 & 38.0 & 1.10 & 81.0 & 41.0 \\
\hline 7 & 181.0 & 21.0 & 17.0 & 14.0 & 41.0 & 1.25 & 93.0 & 45.0 \\
\hline 8 & 55.0 & 10.0 & 6.0 & 9.0 & 32.0 & 0.90 & 38.0 & 30.0 \\
\hline 9 & 22.4 & 23.0 & 17.0 & 15.0 & 43.0 & 1.62 & 101.0 & 61.0 \\
\hline 10 & 192.0 & 25.0 & 19.0 & 16.0 & 45.0 & 1.74 & 97.0 & 44.0 \\
\hline $\begin{array}{l}11 \\
12\end{array}$ & $\begin{array}{l}261.0 \\
2050\end{array}$ & $\begin{array}{l}27.0 \\
240\end{array}$ & $\begin{array}{l}20.0 \\
200\end{array}$ & $\begin{array}{l}17.0 \\
150\end{array}$ & $\begin{array}{l}47.0 \\
440\end{array}$ & $\begin{array}{l}1.82 \\
1.69\end{array}$ & $\begin{array}{l}114.0 \\
990\end{array}$ & $\begin{array}{l}52.0 \\
470\end{array}$ \\
\hline
\end{tabular}

Notes: CFU g ${ }^{-1}$ dry soil $=$ Colony forming unit $/$ gram dry soil, MPN g ${ }^{-1}$ dry soil $=$ Most Probable Number /gram dry soil, $\mathrm{TBC}=$ Total bacterial count, $\mathrm{TFC}=$ Total Fungi count, $\mathrm{TYC}=$ Total yeasts count, $\mathrm{TAC}=$ Total actinomycetes count, TTBC $=$ Total thermophilic bacterial count, $\mathrm{TCBC}=$ Total cellulolytic bacterial count, $\mathrm{TNBC}=$ Total nitrifying bacterial count and TDBC $=$ Total denitrifying bacterial count.

Egypt. J. Soil. Sci. 58, No. 2 (2018) 
The obtained results differ according to the total denitrifying commenting on the aforementioned counts of different microorganisms in the different sites, it is apparent that some sites have considerably higher counts whereas other sites are somewhat lower counts that depend on soil properties of the media used for their growth and these will be evaluated statistically afterwords.

\section{Enzymatic activity of microorganism}

In the studied sites, data presented in Table 6 showed the activities of dehydrogenase, alkaline phosphatase and urease enzymes in the studied sites.

Soil enzyme activities are the driving force behind all the biochemical transformations occurring in soil. Their evaluation may provide useful information on soil microbial activity and be helpful in establishing the effects of soil specific environmental condition (Avanthi et al., 2017). These data showed different variations in their activity as they vary wildely between 1.89 $35.78 \mu \mathrm{molg}^{-1}$ dry soil $\mathrm{hr}^{-1}$ with the highest activity is associated with site 3 and the lowest activity recorded in site 8 . It is also evident that lower value characterises activity of dehydrogenase is in sites $1,2,4,5$ and 8 while somewhat higher activities are recorded in other sites but still below those in sites $3,6,7,9,10,11,12$. With regard to alkaline phosphatase the lowest activity is recognized in site 8 while the highest activity is found in site 3 . Common values around 22.0 are recorded in sites $1,2,4,5,6,8$ whereas higher values are strictly confined to sites $3,7,9,10,11,12$ as usual, whereas activity of urease is not detected in eight sites 1 , $2.4,5,6,7,8$ and 10 while been quite low within the range of $0.75-0.89\left(\mu \mathrm{molg}^{-1} \mathrm{dry}\right.$ soil $\left.\mathrm{hr}^{-1}\right)$ in the other sites .These data irrespective of their variations indicate considerably high activities in site 3 while the other sites have no common activity except in few cases. Soil enzyme activities have been generally accepted as one of the diagnostic indices of soil fertility quality and can quantify changes as a result of human disturbance (Jinlong Yan et al., 2013). Application of enzyme activity as a diagnostic index promotes high sensitivity to external effects, simplicity of definition and low errors (Bhattacharyya et al., 2008). Another study by Yan et al. (2013) who found that there was a significantly positive correlation between soil urease activity and nitrifying activity, indicated that there was a synergistic interaction on them. Also, our results indicated that there are a positive correlation between microbial counts and enzyme activities.

\section{Statistical evaluation of data}

To find out the correlation between the counts of microbiological and enzymatic activates on the one hands and soil properties in different sites under investigation, on the other, correlation computed to figure out the influence of soil parameters on microbiological and biological status in all sites, bearing in mind that $\mathrm{Y}$ values as expressed as $\log _{10}$ (Fig. 3).

Total bacterial count (TBC) is increasing; affected by OM in a curvilinear trend $\left(\mathrm{r}^{2}=0.7298\right)$ TBC tends to increase with $\mathrm{OM}$ increase up to 1.7 $\%$ decreases afterwards. Likewise, total fungi count (TFC) follows nearly the same trend with OM converses $\left(r^{2}=0.7391\right)$. Another pattern is displayed by $\mathrm{pH}$ where TFC tends to increase with increasing $\mathrm{pH}$ up to $8.0\left(\mathrm{r}^{2}=0.3782\right)$. The effect of organic matter rendered respells to aggregate extent, that displayed by total bacterial and fungi counts (TBC and TFC), (Fig. 3). Total yeast count (TYC) increased progressively low with increasing $\mathrm{OM}\left(\mathrm{r}^{2}=0.6965\right)$. An opposite trend is shown by the effect of $\mathrm{EC}, \mathrm{Ca}^{++}, \mathrm{Na}^{+}, \mathrm{Cl}^{-}$ and $\mathrm{SO}_{4}=\left(\mathrm{r}^{2}=0.4175,0.386,0.4215,0.403\right.$ and 0.4432 respectively) where TYC tends to decrease with increasing three variables. The effect of $\mathrm{Ca}^{++}, \mathrm{Na}^{+}$and $\mathrm{SO}_{4}{ }^{=}$is clearly manifested in Fig. 3 where TYC tends to decrease with increasing their concentration while being slightly affected by exchangeable $\mathrm{Na}\left(\mathrm{r}^{2}=0.4028\right)$.

With regard to the effect of exchangeable $\mathrm{Na}$ on total actinomycetes count (TAC) $\left(r^{2}=0.4028\right)$ it is clear that TAC decreased progressively followed nearly the same trend organic matter (OM) tends to increase TAC up to $1.9 \%$ then slightly decreased afterwords $\left(r^{2}=0.7865\right)$. Organic matter affects total thermophilic bacterial count (TTBC). Increasing organic matter (OM) up to $1.8 \%$ increased TTBC while further increase leads to a slight decrease of TTBC $\left(r^{2}=0.8428\right)$. Likewise exchangeable $\mathrm{Na}$ had increased $\left(\mathrm{r}^{2}=\right.$ 0.8428) (Fig. 3).

Increasing $\mathrm{OM}$ up to $1.5 \%$ has slightly increased total cellulolytic bacterial count (TCBC) then decrease progressively $\left(r^{2}=0.8318\right)$, Fig. (3).

The effect of $\mathrm{OM}$ on total nitrifying bacterial count (TNBC) is shown to be slight up to 1.7 $\%$ followed by slight increase $\left(\mathrm{r}^{2}=0.7005\right)$. Exchangeable $\mathrm{Na}$ has depressed TNBC $\left(\mathrm{r}^{2}=\right.$ 0.4928). TDBC tends to increase slightly with organic matter, increase TDBC up to $1.8 \%\left(\mathrm{r}^{2}=\right.$ 0.5752 ). Though the role of clay and silt fractions on total bacteria is not significant,yet their role in surface area and formation of biofilm of bacteria cannot be neglected. 
TABLE 6. Enzymes activity in different soil sites of Abu Suberia Valley

\begin{tabular}{cccc}
\hline \multirow{2}{*}{ Site No. } & & $\boldsymbol{\mu m o l g}^{-1} \mathbf{d r y} \mathbf{~ s o i l ~} \mathbf{~ h r}^{-1}$ & \\
\cline { 2 - 4 } & Dehydrogenase & Alkaline phosphatase & Urease \\
\hline 1 & 4.02 & 22.66 & ND \\
2 & 2.39 & 22.06 & 0.89 \\
3 & 35.78 & 40.07 & ND \\
4 & 3.34 & 22.17 & ND \\
5 & 5.14 & 22.61 & ND \\
6 & 8.39 & 22.66 & ND \\
7 & 12.22 & 29.41 & ND \\
8 & 1.89 & 21.95 & 0.86 \\
9 & 26.64 & 37.59 & ND \\
10 & 15.20 & 29.87 & 0.79 \\
11 & 28.12 & 38.70 & 0.75 \\
\hline
\end{tabular}
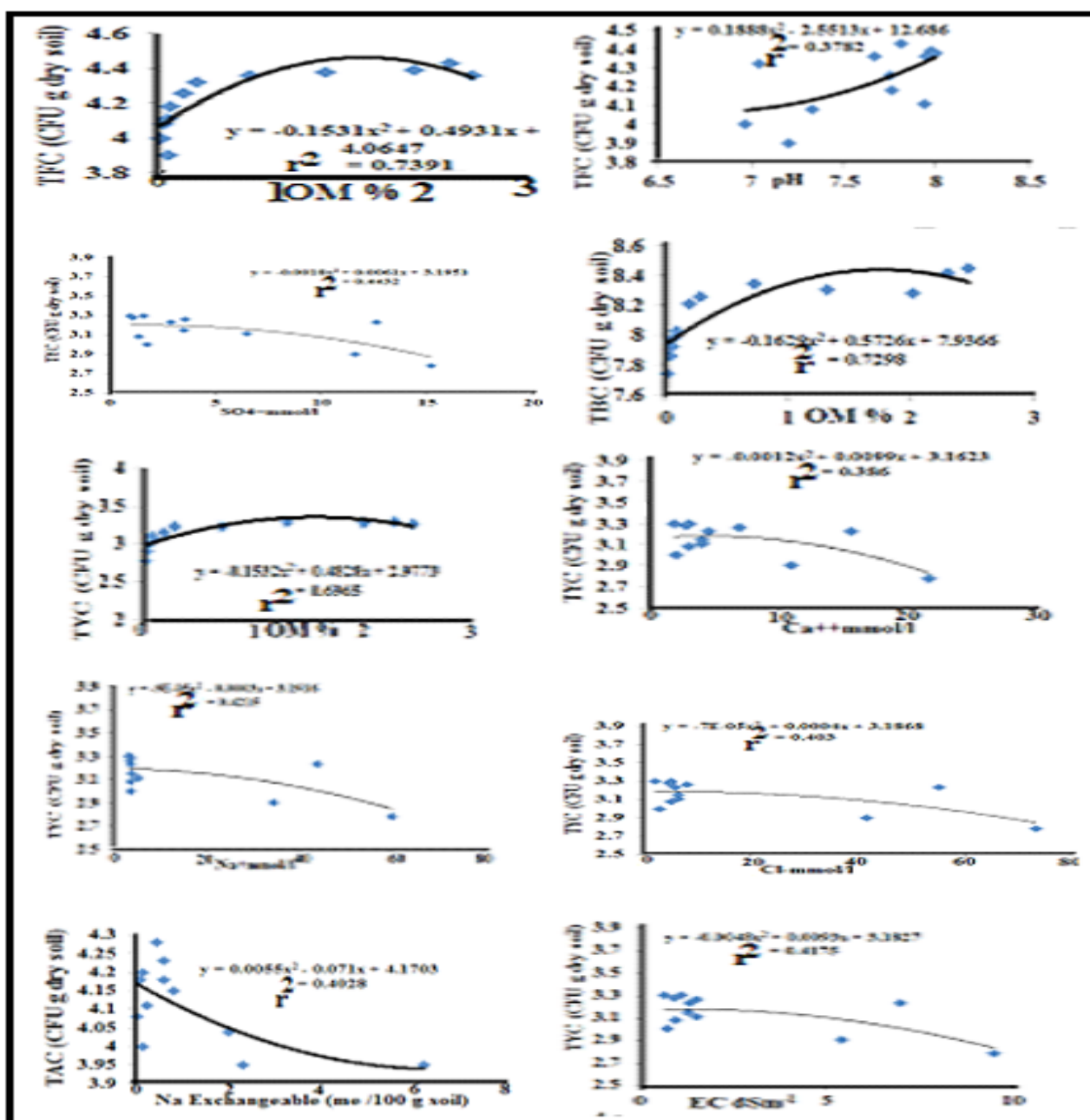

Fig. 3. Relationship between soil properties and total microbial counts in Abu Suberia Valley Egypt. J. Soil. Sci. 58, No. 2 (2018) 


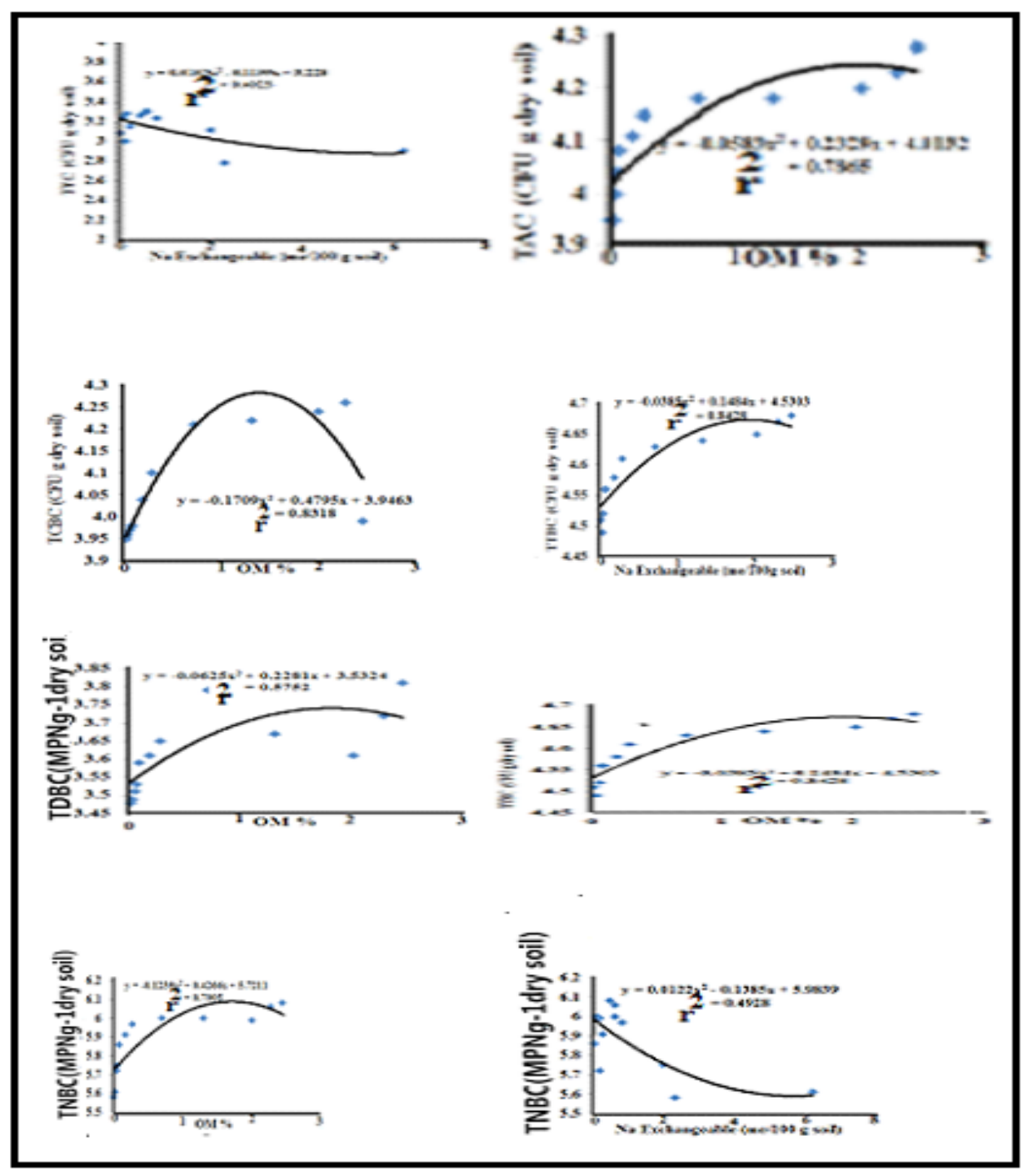

Fig. 3. Cont. Relationship between soil properties and total microbial counts in Abu Suberia Valley

Figure 4 describes the effect of $\mathrm{OM}$ on the biological activities, as a straight curvilinear trend of higher magnitude, for dehydrogenase $\left(\mathrm{r}^{2}=0.7691\right)$ and urease $\left(\mathrm{r}^{2}=0.5491\right)$ relative to alkaline phosphatase $\left(r^{2}=0.764\right)$. In other words, the increase of OM has increased dehydrogenase and urease progressively while being slightly lower for alkaline phosphatase.

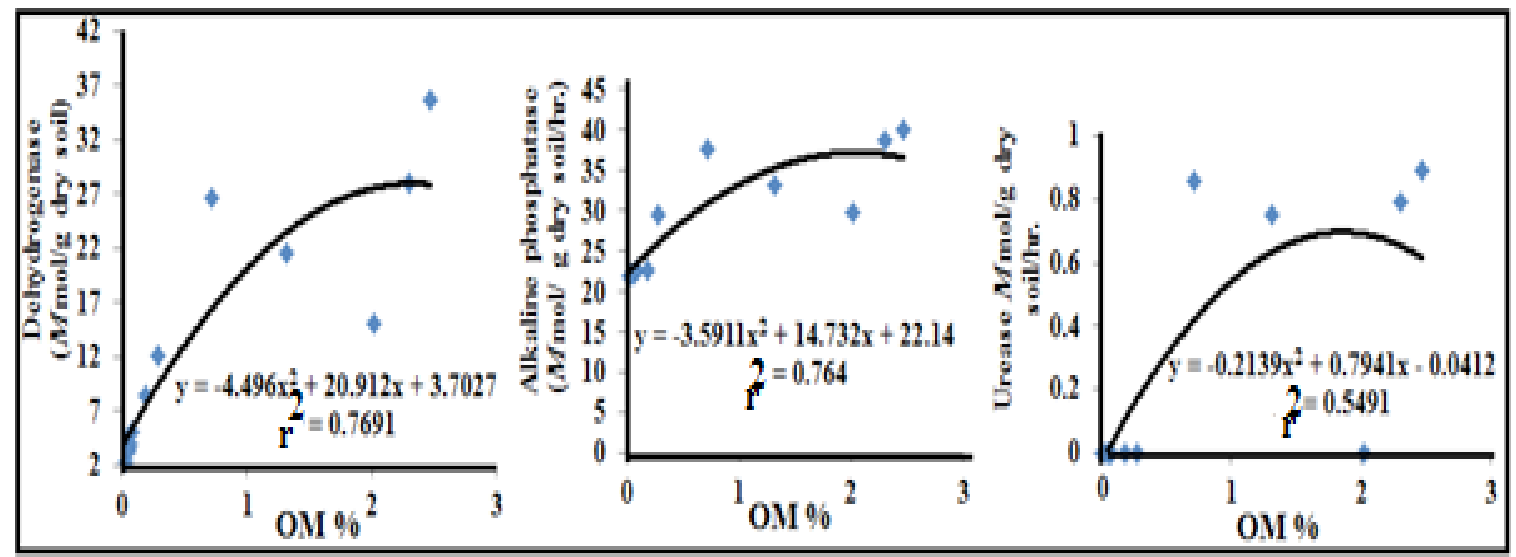

Fig. 4. Relationship between soil properties and enzymes activities in Abu Suberia valley 


\section{References}

Andreoni V., Cavalca L., Rao M.A., Nocerino G., Bernasconi S., Dell Amico F., Colmbo M. and Gianfreda L. (2004) Bacterial communities and enzyme activites of PAHs polluted soil. Chemosphere, 57 (5), 401-12.

Avanthi, D.I., Sang, S. L., Nabeel, K. N., Young, H. L., Kye, H., Jeong, H., Park, D. H. M. and Yong, S.O. (2017) Assessment of Soil Health in Urban Agriculture: Soil Enzymes and Microbial Properties. Sustainability, 9(2), 310.

Becky, H., Martin., H., Joanna, H. (2001) How to optimize the drop plate method for enumerating bacteria. J. of Micro. Meth. 44,121-129.

Ben-David, A. and Davidson C.E. (2014). Journal of Microbiological. Methods, 107 214-221.

Bhattacharyya, P., Tripathy, S., Kim, K., and Kim SH. (2008) Arsenic fractions and enzyme activities in arsenic-contaminated soils by groundwater irrigation in West Bengal. Ecotoxic Environ Safety, 71, 149- 156.

Bridson, E. Y. (2006) Oxoid Manual. (Substantially revised) (Former Technical Director of Oxoid), $9^{\text {th. }}$ ed.

Caldwell, B. (2005) Enzyme activities as a component of soil biodiversity: A review. Pedobio.49,637-644.

Dawid, J. and Dorota, K. (2014) A comparison of methods for the determination of cation exchange capacity of soils. Ecol. Chem. Eng. S., 21(3), 487-498.

De Vos, B., Lettens, S., Muys, B. and Deckers, J. A. (2007) Walkley-Black Analysis of Forest Soil Organic Carbon: Recovery, Limitations and Uncertainty. Soil Use Manage. Doi: 10.1111/ j.1475-2743.2007.00084.x

Dixon, J.B. and Schulze, D.G. (2002) Soil Mineralogy with Environmental Applications. Soil Sci. So. of Ame., Madison, Wisconsin, USA.

Ehrmann, W., Setti, M., and Marinoni, L. (2005) Clay minerals in Cenozoic sediments off Cape Roberts (McMurdo Sound, Antarctica) reveal palaeoclimatic history. Palaeogeography, Palaeoclimatology, Palaeoecology, 229, 187-211.

Gavlak, R. G. D., Horneck, A., and Miller, R. O. (2005) Soil Plant and Water Reference Methods for The Western Region. WREP-125, $3^{\text {rd }}$ ed.

WHO and Switzerland. (2017) Guidelines for DrinkingWater Quality. fourth edition incorporating the first

Egypt. J. Soil. Sci. 58, No. 2 (2018) addendum. Cataloguing-in-Publication. Interligar, Brazil, Data ISBN 978-92-4-154995-0.

Hirotsugu, F., Asami, K., Norisuke, U., Kengo, M. and Statoshi, T. (2015) Selective isolation of ammoniaoxidizing bacteria from autotrophic nitrifying granules by applying cell-sorting and sub-culturing of microcolonies. Front Microbiol. 6 . 1159. Doi: 10.3389/fmicb.201501159.

Harris, W.G., and White, G.N. (2007) X-ray Diffraction Techniques for Soil Minerals Identification. Soil Sci. So. of Ame., Methods of Soil Analysis. Part 5. Mineralogical Methods. SSSA Book Series, No.5. Madison, Wisconsin USA.

Li, Y. H., and Schoonmaker, J. E. (2003) Chemical composition and mineralogy of marine sediments. In: F. T. Mackenzie (Ed.) Sediments, Diagenesis, and Sedimentary Rocks. Treatise on Geochemistry V. 7. Amsterdam: Elsevier.

Jinlong, Y., Guixiang Q., and Cheng, D. (2013) Effects of the combined pollution of lead and cadmium on soil urease activity and nitrification. Procedia Environmental Sciences, 18, 78 - 83.

Julien, M., (2016) The soil texture wizard: R functions for plotting, classifying, transforming and exploring soil texture data.

Maite, M., Asicent, R.,B., Francisco, L., and Juan, J. (2005) Bacteriophages May Bias Outcome of Bacterial Enrichment Cultures. Appl. Environ. Microbiol. 71 (8), 4269-4275.

Matsumoto, S., Ishikawa, D., Saeki, G., Aoi, Y., and Tsuneda S. (2010) Microbial population dynamics and community structure during the formation of nitrifying granules to treat ammonia-rich inorganic wastewater. MicrobesEnviron. 25,164-170. 10.1264/jsme2.ME10107.

Ostafiychuk, B.K., Budzulyak, I.M., Ivanichok, N.YA. Rachiy, B.I., and Lisovsky, R.P. (2014) The effect of thermal modification on the development of carbon material microporous structure. J. l of Vas. Stef. Proc. Nat. Univ., 1 (1), 41-53.

Peters, J., Combs, S., Hosklns, B., Jarman, J., Kovar, J., Watson, M., Wolf, A., and Wolf, N. (2003). Recommended Methods of Manure Analysis. University of Wisconsin-Madison.

Pious, T., Aparna, C., Sekhar, R., Upreti, M., M., and Sadiq, S. P. (2015) Optimization of single plateserial dilution spotting (SP-SDS) with sample anchoring as an assured method for bacterial and 
yeast cfu enumeration and single colony isolation from diverse samples. Biotechnology Reports, 8, $45-55$.

Schloter, M., Dilly, O. and Munch, J.C. (2003) Indicators for evaluating soil quality. Agri., Eco., and Env. 98, 255-262.

Silva, N. R. N., Lathiff, M. A. and Maraikar, S. (2007) Simple and rapid test method for assessing available N,P,K levels in soil. J. Soil Sci. Sri Lanka, 19.

Soil Survey Staff. (2009) Soil Survey Field and Laboratory Methods Manual. Soil Survey Investigations Report No. 51, Ver. 1.0. R. Burt (Ed.). U.S. Depa. of Agri., Nat. Res. Cons. Ser.

Syvitski and James, P. M. (2007). Principles, methods and application of Particle Size Analysis. Cam.
Univ.

USDA, (2010) Keys to Soil Taxonomy. Uni. Sta., Depa. Of Agri.,11 th. ed. USA.

Yan, J., Quan, G. and Ding, C. (2013) Effect of the combined pollution of lead and cadmium on soil urease activity and nitrification. Proc., Env. Sci., 18, 78-83.

Zhao, Y., Zhao, D., and Daoliang, L. (2015) Electrochemical and Other Methods for Detection and Determination of Dissolved Nitrite: A Review. Int. J. Electrochem. Sci., 10, $1144-1168$.

(Received: $1 / 11 / 2017$; accepted:12/ 3 / 2018)

\section{خصائص التربه وأثرها على بعض الأنثطه البيولوجيه فى وادى أبوصبيرهـ أسوان ، مصر}

شيماء إبراهيم أحمد على'، سمير أحمد مرغنى محجوب"، نبيل محمد عبداللطيف بهنساوى " و صلاح طاحون؛

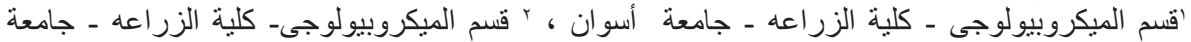

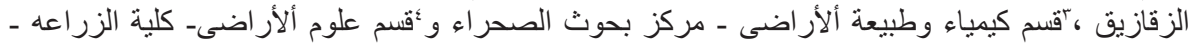

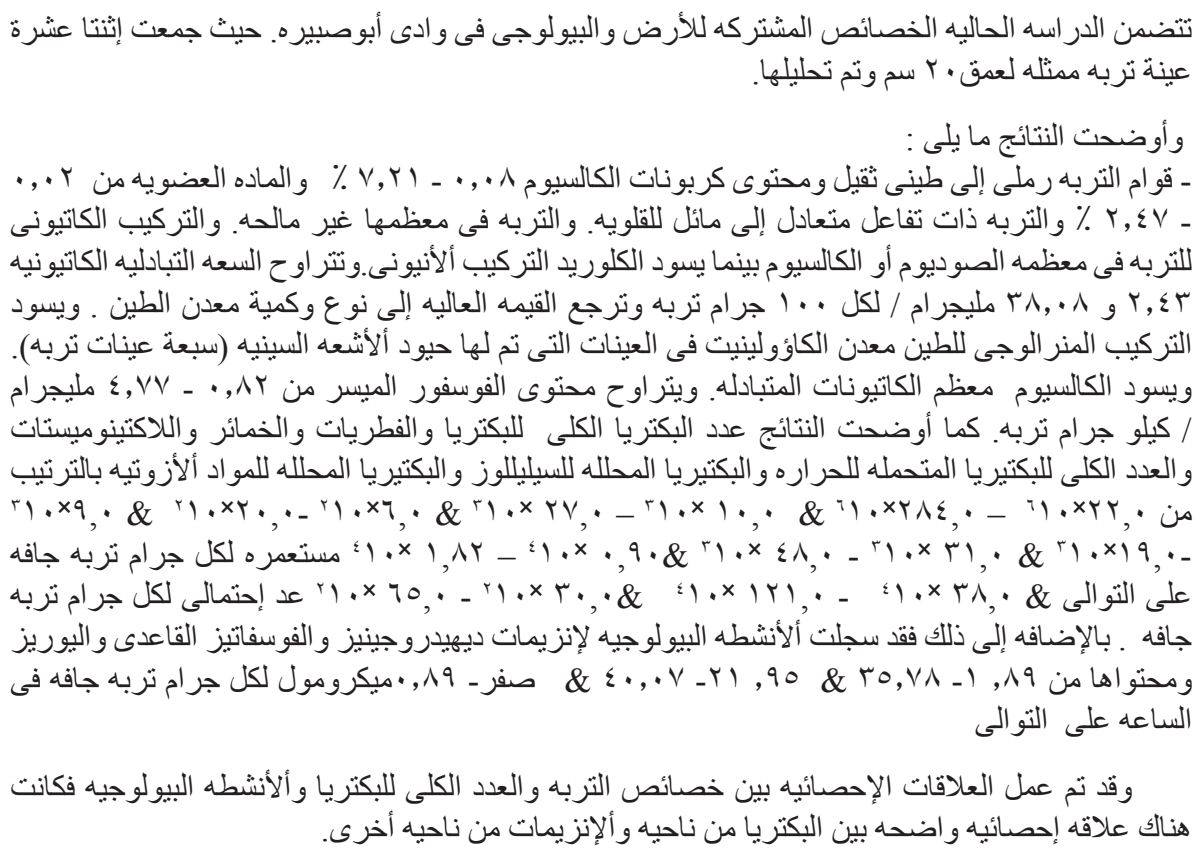

